\title{
Factors affecting labour absorption in South Africa
}

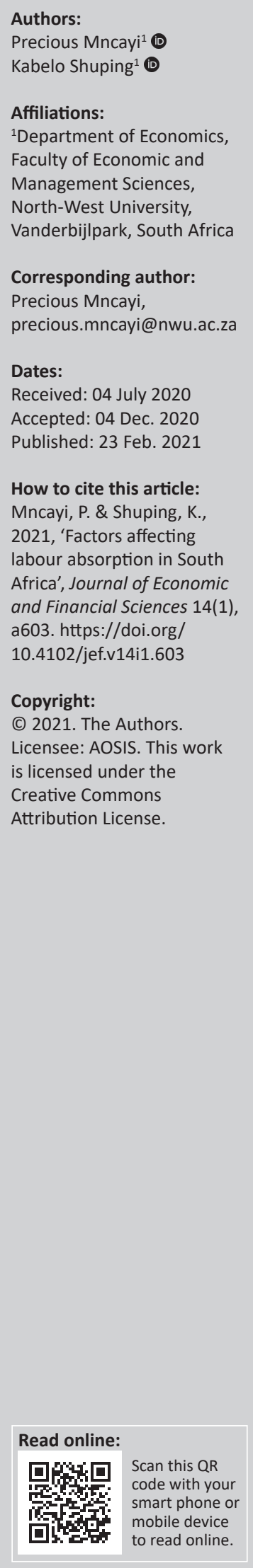

Orientation: South Africa's continually growing unemployment rates appear to be acute if measured by means of labour absorption. The country's labour continues to struggle being absorbed in the labour market, let alone finding good and sustainable employment, hindering potential economic growth and development.

Research purpose: The study aims to analyse and understand factors affecting labour absorption in South Africa.

Motivation for the study: South Africa is characterised by limited job opportunities and a rapidly expanding labour force. Therefore, critically understanding factors contributing to low absorption rates could assist in harnessing and re-evaluating the effectiveness of existing labour policies.

Research approach/design and method: The study uses quarterly time series data from 2008Q2 to 2019Q1. The Autoregressive Distributed Lag (ARDL) model was used to estimate the long-run and short-run relationships between the chosen variables.

Main findings: The study found a long-run relationship between the selected variables and labour absorption. One main finding is that in the long run, the number of male work-seekers leads to a declining labour absorption rate, whilst the number of female work-seekers results in an increase in labour absorption.

Practical/managerial implications: For many years, females have endured negative employment outcomes as a result of existing inequalities in the labour market. The findings of this study reveal the potential effectiveness of South Africa's employment policy in reversing such statistics. A further study with a more defined focus on labour absorption, employment policy and gender should be undertaken to enhance the understanding on labour's absorptiveness in the labour market.

Contribution/value-add: Labour absorption is a broader measure of labour market performance than unemployment, because it comprises the labour force participation behaviour. Therefore, this study takes a much broader angle than most studies on unemployment.

Keywords: labour absorption; unemployment; labour market; employment; working age; South Africa.

\section{Introduction}

A critical analysis of labour market transitions is crucial in understanding the complex nature of unemployment. The phenomenon of shrinking employment has become a chronic socioeconomic issue in South Africa and around the globe. Leading up to 2008, South Africa's economy grew tremendously, experiencing high levels of economic growth following the beginning of democracy until the global recession in 2008 (World Bank 2018). Despite the positive economic performance, the country was still not able to generate sufficient employment opportunities for its continually growing labour force, making unemployment one of South Africa's chronic issues together with poverty and income inequality (Meyer 2014:65-77). The transition into the labour market has been prolonged mainly because of chronic levels of unemployment, and this indicates that people are not being absorbed into the labour market, and the longer they are without employment, the slimmer their chances of finding one. Globally, young people are the most vulnerable, with unemployment rates that double the national averages (World Bank 2018), and South Africa is not excluded. The acute proportions of prolonged unemployment levels necessitate a re-evaluation of contemporary labour policies to harness the labour absorptive capacity of the country.

According to Charles, Hurst and Schwartz (2019), it is assumed that rapid economic growth sustained by a dynamically industrial sector would eventually attract a large number of flows of 
new labour force in the labour market. Industrial sector employment has been regarded as the most important driving sector of employment; however, it tends to produce insufficient results, even in cases where an economy is growing at a rapid pace (Charles et al. 2019). According to Posel and Casale (2003), labour absorption is primarily discussed as a supply-side variable, which provides a different indication to the unemployment rate regarding the lack of employment opportunities in the labour market. A higher labour absorption means more work-seekers are getting employed, whilst a lower absorption rate shows more people are struggling to find employment (Stats SA 2020). The mechanisation of the labour market has implied that a large pool of unskilled labour in these countries with high unemployment rates is often left on the brink, with no hope of sustainable employment, leaving people trapped in the vicious cycle of poverty. The consequence is that if people face prolonged periods before transitioning into the labour market, an erosion of human capital results beyond the economic and psychological effects. According to Oosthuizen and Bhorat (2005), South Africa is not without any exceptions as, despite the substantial transformation its economy has undertaken since 1994 to correct the disproportions of the past through the execution of several labour regulation policies, the labour market remains under significant pressure. Notwithstanding improved economic growth rates throughout the 1990s and early 2000s, these have not been complemented by increased use of the country's labour resources (Bhorat et al. 2014). The joblessness growth has presented worrying concerns with continually declining employment rates. The question remains: What has been fuelling these poor absorption rates? Against this background, the study in question aims to critically understand factors affecting labour absorption rates in South Africa.

\section{Literature review}

\section{Overview of labour market dynamics in South Africa}

As it is known, the distinctive nature of the South African labour market is the dominance of high levels of unemployment as compared with other developing economies. This can ultimately be attributed to a number of factors such as real wage rate and gender disparity (Bhorat \& Khan 2018). In the past two decades, the country's labour market has undertaken considerable transformations. The most apparent change being relative joblessness growth, with the official unemployment rate currently one of the highest in the world at 29.1\% (Stats SA 2019).

Figure 1 denotes the trend of labour absorption in the South African labour market. It can be seen that the employment rate has been sluggish since post-2008. Undoubtedly, this can be attributed to global economic collapse that took place in late 2008. This ultimately led to job losses across the globe (Verick \& Islam 2010). It is clear that the economy has not been able to fully recover since the global economic crisis. Despite the continually rising unemployment and low absorption rates, the working-age population has been

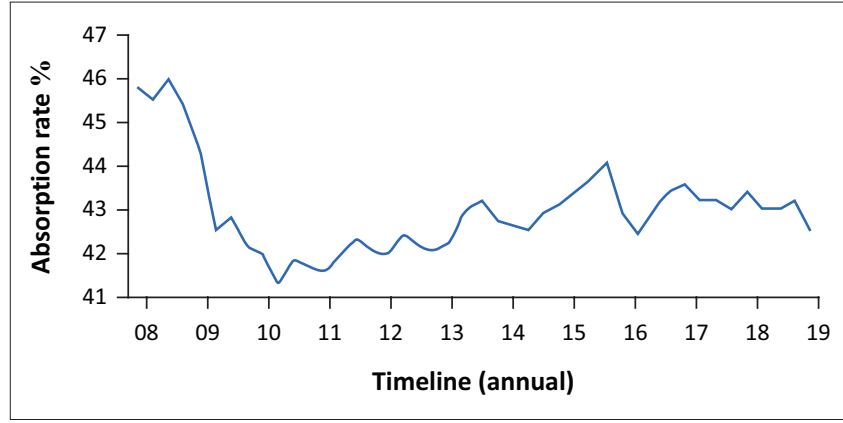

FIGURE 1: Labour absorption rate of 2008-2019.

shown to increase over time. The absorption rate remained constant at $42.2 \%$, whilst the unemployment rate and labour force participation rate increased by $0.1 \%$, respectively. The unemployment rate lies at $29.1 \%$ in the fourth quarter of 2019 , whereas the labour force participation rate is at $59.9 \%$ (Stats SA 2019). The economy has seen the largest employment expansion in the formal sector, with 43000 work-seekers absorbed in the labour market, followed by the agricultural sector and private households at 38000 and 35000, respectively, in quarter three of 2019. In contrast, the informal sector employment has declined by 53000 in quarter three of 2019 compared with that of quarter two. The number of discouraged work-seekers has substantially increased by 44000, whilst those who are economically active have lowered down with 35000 between the second quarter and third quarter of 2019 (Stats SA 2019).

As characterised by Kingdon and Knight (2004), continually increasing unemployment rates can be attributed to increasing labour force participation rates, slow economic growth and inflexibility in the labour market. The South African labour market suffers from the dominance of unequal access to job opportunities and labour discrimination. The unemployment burden was particularly prevalent amongst the mixed-race and black people, whilst the minority of white people enjoyed employment absorption. For instance, one place where racial inequality was prominent, was jobs in government administration (Leibbrandt et al. 2010). Black people did not only suffer relatively high unemployment rates but also low wages; this was observed by low paying jobs relatively reserved for black people, whilst white people had higher paying jobs (Leibbrandt et al. 2010). South Africa is no exception to a spatially segregated workforce, largely because of apartheid policies. Therefore, this explains low absorption rates of particularly black people in the labour market.

Not all jobs are equally created and many are not considered in the category of the formal sector. Informal jobs are regarded as those within the labour market but not formally registered, for instance domestic workers (Hundley 2001). Generally, workers operating within the informal sector are without labour rights and protection as preserved by the South African Labour Regulations. Therefore, this group of workers is prone to exploitation of increased working hours and lowwage rates. The informal sector is generally accepted as the 
last resort for the large pool of unemployed labour (Bhorat, Dieden \& Hodge 1998). Considering the magnitude of the unemployment rate in South Africa, one would assume the informal sector to have a fairly large pool of labour absorption (Potts 2008).

The labour market remains under critical observation; the persistent joblessness growth has continued to present worrying concerns to the labour market. In fact, the South African labour force is expanding rapidly, particularly the number of new graduates transitioning into the labour market. As a consequence, the transition into the labour market is prolonged because of long-lasting levels of unemployment. There remains a gap in understanding the predominant factors affecting labour absorption rates in South Africa. With this study being under-researched, it now remains a complex picture as to how these factors contribute to the lack of understanding about what predominately affects labour absorption. Now the question remains, beyond human capital, what factors hold relevance to labour absorption?

\section{Contextual background}

At the core of the subsequent labour market debates, labour market rigidities are considered to be one of the binding constraints to labour absorption. Labour market rigidity or poor labour market efficiency is detrimental to the labour absorption of the country. According to Schwab (2018), South Africa ranks 93rd out of 137 on measures associated with labour market efficiency. Labour market efficiency assumes that there are no distortions within the labour market such as the hurdles associated with transitioning in the labour market. Analysing the structure of South African labour market, it is imperative to consider the sociohistorical patterns that shape it, taking into account the racialised wage disparities, the rural and urban separation embedded by the apartheid government, the distances from the residence places to workplaces, as well as apartheid regulations that restricted the expansion of the informal sector. South African labour legislation is to be held responsible for prolonged levels of unemployment and low absorption rates. The lack of labour law transformation has seen inequality increase in the workplaces and it is undoubtedly visible that labour laws exacerbate high levels of unemployment. Economic growth has been too sluggish to absorb a large number of work-seekers into the labour market, since 1970, whilst at the same time strict labour laws have had a considerable impact on South African labour market (Bernstein 2020). The laws have resulted in increased costs of hiring and this ultimately has affected the vulnerable groups of youth and unskilled labour.

Labour market rigidities, particularly in developing economies with an abundance of unskilled labour, have a tendency to create social tensions and contribute towards high levels of unemployment. As indicated by Banerjee et al. (2008), job search continues to be ineffective for the majority of black work-seekers as compared with their white counterparts, which is largely because of spatial separation of where the work-seekers reside and the places of future employment. This significantly contributes to high transport costs, which become a constraining factor for job searching. One possible explanation of this phenomenon is that high job search slows down the transition in the labour market (Banerjee et al. 2008). As economic stance improves, youth is the first cohort to be disregarded for employment opportunities. The labour market rigidity and ineffective labour laws are notable factors contributing to low absorption rates (Bazen \& Skourias 1997). However, as noted by Kingdon and Knight (2007), the barriers to entry in the informal sector such as high start-up capital and costs have focused on the potential growth of employment, consequently affecting the labour absorption of informal sector. Unlike in other developed countries, labour in informal sectors experiences difficulties in transitioning to the formal sector.

Another distinguished barrier to a larger labour absorption in the labour market is the levels of educational attainment and the quality of education; precisely, the mismatch between the skills of the education system and the demands of the labour market. South Africa has a sluggish labour absorption rate of $42.2 \%$ with a decrement of $0.2 \%$ (Stats SA 2019). It is widely known that formal education intensifies the chances of being absorbed in the labour market, relative to those without formal education (Moleke 2005). In contrast, radical improvement in education is not necessary for work in the manufacturing sector (Chandra \& Khan 1993). From a theoretical perspective, the job search theory argues that searching for a job is regarded as a dynamic sequential procedure and work-seekers are required to discontinue the process under the circumstances of imperfect information and uncertainty (Van den Berg 1990). Therefore, according to this theory, labour market participants constantly encounter prolonged spells of unemployment essentially because of a lack of information on available job openings, location, required skills and qualifications (ed. Faggian 2014:59-73). From a migration perspective, the chances of finding a good matching job are determined by an individual migrating to a different destination (Elricka \& Lewandoska 2008).

The job search theory distinguishes the two factors of migration as speculative and contracted. Work-seekers undertake the decisions of migrating in the hope of being presented with a perfect fitting or suitable employment opportunity (Pickles \& Rogerson 1984). Therefore, this theory assumes that migration must come first before the job search since regions dominated by large wage changeability absorb more labour, whereas regions with large non-pecuniary wages are subject to high rates of labour migration. Jackman and Savouri (1992) contended that because regional variances are dominant in the depression phase, the constructed human-capital model will assume that people migrate from poorer peripherals to richer regions during recession, but it has been proven that the flows of migration tend to increase during the prosperity phase. 
Labour is absorbed when it is needed to reinstate the stability to the economy. The human capital theory is a neoclassical concept; therefore, the decision for a work-seeker to migrate basically depends on the assessment of future benefits or wages associated with the job market (Sjaastad 1962). Employers respond to economic predicaments by cutting recruitments, and therefore the job-finding becomes difficult for individuals. Consequently, the role of information costs should also be taken into account because the information costs intensify when the distribution of jobs becomes sporadic. Furthermore, if work-seekers perceive economic crises, expected reservation wages decline because jobs with lower wages are vacant (Diamond 1982). Previous studies in the wage reservation research area have indicated that the individual's skills capacity is an important aspect leading to a secure process of finding a job; in this regard, this ultimately assists the work-seekers to measure their skills against the job offer by means of wage rate comparison. As such, this will confirm whether the work-seeker finds the job suitable or unfitting (McCall 1970).

\section{Empirical review on the determinants of labour absorption}

According to the Institute for Race Relations (2017), the crisis of labour market absorption is mainly centred on black South Africans rather than whites. The findings of the study indicate that approximately four in ten black South African working population are employed, implying that the labour absorption of black South Africans is approximately $40 \%$. The analysis of the study further showed that the South African labour absorption rate is assumed to be mainly dependent on an individual's level of education. For instance, labour market absorption for people with tertiary education is approximately $75.6 \%$. On the other hand, those with matric as their highest level of education are approximately 50.3\% (Institute for Race Relations 2017). Another study conducted by Bhorat and Leibrandt (1999) on returns to education established that lower levels of education did not improve the chances of being absorbed in the labour market. Therefore, a higher level of education has a substantial influence on gaining employment and increasing returns. These findings coincided with those of Van der Berg and Burger (2003). In support of education being an important factor, Moleke (2005) reported that university education offers returns to employable future. It was also indicated that within a span of 6 months, approximately $88 \%$ were absorbed into the labour market, with $60 \%$ of those with tertiary education being absorbed immediately after completing their studies (Moleke 2005).

This clearly shows that the level of education eases the hurdles of absorption in the labour market, given the staggering unemployment rates in South Africa. The characteristics of shrinking employment in South Africa have been attributed to the factors relating to labour policies formulated by the apartheid government in order to foster separate development (Altman 2003:158-183). For instance, the constraints of labour supply were mainly characterised by labour market restrictions and population control (Altman 2003:158-183). This approach of separate development has restricted labour absorption by converting the economy into a capital-using market, significantly raising the number of unemployed people, leading to the sluggish labour absorption. The general theory of employment, advocated by Keynes (1936), assumes that, in the economic framework, the number of employment levels corresponds to the level of demand in terms of wage-units, and therefore the job search will cease once the wage expectations are proportional to wage offers by the firm. This theory adds on to explain that the demand for labour hinges on the level of production. The classical theory assumes that real wages are proportional to inefficiency of labour and that labour negotiates their wages with the employers. Notably, the assumption that the wage rate is the only factor explaining the decisions of work-seekers can be disregarded, because the labour supply model entails that the choice is made on the basis of number of hours and participation (Bloemen 1997). The next section encompasses the methodological processes followed in the study.

\section{Methodology Data and variable description}

The objective of this study is to analyse factors affecting labour absorption in South Africa. In achieving the objectives, the study uses secondary data from 2008Q2 to 2019Q1 that is based on 44 quarterly observations. Therefore, a quantitative research design and functionalist approach are considered to be a suitable design choice. Econometric Views (E-views) version 10 was used as the statistical tool to run the models. Furthermore, it should be known that the variables were not transformed into logarithmic form because they were stable and stationary. Variables of the study were obtained from Statistics South Africa and the South African Reserve Bank and adjusted into quarterly basis. Table 1 specifies the variables used and their proxies.

\section{Labour absorption (Y)}

The controversy surrounding the issue of employment in South Africa has raged unabated for many years. The critical question of this study is to determine factors contributing to relatively low absorption rates in South Africa.

\section{Youth 15_34 (X)}

This age group represents the youth group who were chosen mainly because of findings that they are more likely to be

TABLE 1: Variable specification.

\begin{tabular}{ll}
\hline Proxy & Description \\
\hline LabourAbs & Labour Absorption $(\mathrm{Y})$ \\
Age15_34 & Youth 15_34 $(\mathrm{X})$ \\
Age35_54 & Experienced-cohorts $(\mathrm{X})$ \\
Workseekers-Fem & Female work-seekers $(\mathrm{X})$ \\
Workseekers_Male & Male work-seekers $(\mathrm{X})$ \\
BusConf & Business confidence $(\mathrm{X})$ \\
GFCF & Gross fixed capital formation $(\mathrm{X})$ \\
\hline
\end{tabular}


vulnerable to poor labour market outcomes (see Branson et al. 2019; Mlatsheni \& Ranchhod 2017).

\section{Experienced cohorts 35_54 (X)}

This group is representing the cohort with work experience; the group was chosen over those 55-64 age category mainly because the latter may not be actively aggressive in their pursuit of employment relative to the former. Also, those older than 54 years are looking to retire, hence most may not be looking to be absorbed into the labour market.

\section{Female work-seekers $(X)$ and male work-seekers (X)}

These two groups were specifically chosen to determine which gender has more chances of finding employment owing to employment labour policies.

\section{Business confidence index $(X)$}

This variable represents the business developments in the country, which are regarded as one of the factors that may influence employment decisions of employers.

\section{Gross fixed capital formation (X)}

This variable indicates the domestic investment in South Africa. In particular, it was chosen to understand the impact of domestic investment in employment levels.

\section{Model specification}

The study used autoregressive distributed lag (ARDL) to capture the influence of selected variables on labour absorption rates in South Africa. According to Arodoye and Iyoba (2014), the ARDL strength lies in its ability to produce consistent results over other models, hence the reason for making use of the model in this study. Moreover, Pesaran and Shin (1997) stated that the ARDL model allows the use of data despite the order of integration, for example, a mixture I (0) and I (1). The estimated equation will be expressed as:

$$
\begin{aligned}
\Delta \text { LABSORP }_{t}= & \alpha_{0}+\sum_{i=1}^{n} \beta_{1 i} \text { LAGE15_3 }_{t-i}+ \\
& \sum_{i=1}^{n} \beta_{2 i} \Delta \text { LAGE35_54 }_{t-i}+ \\
& \sum_{i=1}^{n} \beta_{3 i} \Delta \text { LWORKSEEKERS }_{\text {aal }_{t-i}}+ \\
& \sum_{i=1}^{n} \beta_{4 i} \Delta \text { LWORKSEEKERS }_{\mathrm{Fem}_{t-i}}+ \\
& \sum_{i=1}^{n} \beta_{5 i} \Delta \text { LBUSCONF }_{t-i}+\sum_{i=1}^{n} \beta_{6 i} \Delta \text { LGFCF }_{t-i}+ \\
& \phi_{1} \text { LAGE15_34 }_{t-1}+\phi_{2} \text { LAGE35_54 }_{t-1}+ \\
& \phi_{3} \text { LWORKSEEKERS }_{\text {Male }_{t-1}}+ \\
& \phi_{4} \text { LWORKSEEKERS }_{\mathrm{Fem}_{t-1}}+ \\
& \phi_{5} \text { LBUSCONF }_{t-1}+\phi_{6} \text { LGFCF }_{t-1}+\varepsilon t
\end{aligned}
$$

where $\triangle$ LABSORP basically denotes labour absorption rate at time $(t)$. Both $\triangle$ LAGE15_34 and $\Delta$ LAGE35_54 at time $(t)$ indicate the youth age group and experienced cohorts, respectively, whilst $\triangle$ LWORKSEEKERS_Male and $\triangle$ LWORKSEEKERS_Fem at time $(t)$ signify the total number of new male and female entrants in the labour market correspondingly. $\triangle \mathrm{LBUSCONF}$ at time $(t)$ indicates the output growth of the economy, whilst $\triangle$ LGFCF signifies investment in equipment and machinery at time $(t)$. $\beta 1$ to $\beta 7$ shows the short-run dynamics, whilst the long-run relationship and the error term are both represented by $\phi 1$ to $\phi 7$ and $\varepsilon t$, respectively.

First of all, to confirm stationarity and stability of the model amongst the selected variables, the study will conduct certain diagnostic tests and augmented Dickey-Fuller (ADF) unit root analysis. The ADF test is undertaken to determine the order of integration and unit root analysis. The hypothesis of the test is as follows:

\section{$H_{0}$ : Series has unit root \\ $H_{1}$ : Series has no unit root}

Moreover, to determine the long-run equilibrium between the independent variables and dependent variables, an ARDL model is conducted. The following hypothesis testing for cointegration is suggested:

\section{$H_{0}:$ No cointegration \\ $H_{1}$ : Cointegration}

According to Pesaran, Shin and Smith (2001), in testing for the two hypotheses, a bounds test is conducted through the Wald $f$-test. The null hypothesis of no long-run equilibrium is rejected if the F-statistic value is greater than both lower bound and upper bound critical values. This will indicate the presence of a long-run equilibrium between the explained variable and explanatory variables of the conducted study. If the estimated critical values of both upper bound and lower bound are less than the F-statistic value, it is an indication of no long-run relationship between the explanatory variables and explained variable. As a consequence, $H_{0}$ cannot be rejected (Mothibi \& Mncayi 2019). If there exists a cointegration between the selected variables, then it suggests the estimation of the error correction model (ECM). In order to calculate the speed of adjustment concerning the long-run relationship, the error correction term is used. Moreover, in trying to determine the appropriate optimal number of lags, the study utilised the Schwarz Bayesian information criterion as proposed by Brooks (2014). This criterion provides consistent and accurate results despite the sample used in the study analysis. In determining the diagnostics stability test of the model, the study conducted the normality, heteroscedasticity, serial correlation and Cumulative Sum of Recursive Residuals (CUSUM) test. The results are presented and discussed in the 'Results' section. 


\section{Ethical consideration}

This article followed all ethical standards for research without direct contact with human or animal subjects.

\section{Results \\ Correlation analysis}

The Pearson correlation was conducted to determine the equilibrium and strength between the selected variables (Table 2). In reference to Gogtay and Thatte (2017), correlation analysis is used to determine the association between two or more quantitative variables. The correlation coefficient value of the correlation is considered to range between -1 and +1 . A correlation coefficient closer to +1 indicates that there is a perfect association between two variables, in a linearly positive manner, whilst a correlation coefficient of -1 specifies that the two variables are perfectly linearly related in a negative way. A correlation coefficient of 0 denotes that no linear association exists between two variables being considered. Table 2 presents the correlation analysis between labour absorption and selected variables. According to the results presented in Table 2, there appears to be a weak positive relationship between age15_34, age35_54 and labour absorption; age15_34 has proven to be statically significant at $0.05 \%$ significance level, whilst age35_54 is not statistically significant. The correlation between labour absorption and variables male work-seekers, female work-seekers and business confidence has shown to be perfectly negative. Surprisingly, male work-seekers and female work-seekers are both statistically insignificant at the 0.05 significance level, whilst business confidence is statistically significant.

\section{Unit root testing}

The unit root analysis was one of the tests conducted before determining the ARDL model (Table 3). To analyse the degree of stationarity, the study has followed a unit root test through the standard ADF test. The significance of this test was undertaken to ensure stationarity and check the order of integration of the variables. The test was conducted on three different specifications; intercept, intercept with no trend and none. The results from this study have shown that no series is integrated of order 2 and above; otherwise, it would not have allowed for ARDL conduction. In addition, it is significant to ensure that the variables are not spurious or do not give false results.

As indicated by Dickey-Fuller, the ADF test examines the existence of unit root and order of integration in a time series data. Therefore, the hypothesis testing is as follows:

Null hypothesis: Series has a unit root

\section{Alternative hypothesis: Series has no unit root}

The results have also proven that all seven variables are not stationary in their levels. Moreover, the results have shown that the variables are stationary when first differenced. Therefore, the series are integrated of the same order. This implies that the series has I(1) integration order. Furthermore, since no variable of the study was found to be integrated of second order $\mathrm{I}(2)$, the outcome of unit root analysis has allowed for ARDL test. The null hypothesis of unit root is, therefore, non-rejected by the ADF test.

TABLE 2: Estimated correlation matrix results.

\begin{tabular}{|c|c|c|c|c|c|c|c|}
\hline $\begin{array}{l}\text { Correlation } \\
\text { probability }\end{array}$ & Labour absorption & AGE15_34 & AGE35_54 & $\begin{array}{l}\text { WORKSEEKERS_ } \\
\text { MALE }\end{array}$ & $\begin{array}{l}\text { WORKSEEKERS_ } \\
\text { FEM }\end{array}$ & BUSCONF & GFCF \\
\hline ABSORP & 1.000000 & - & - & - & - & - & - \\
\hline AGE15_34 & $\begin{array}{l}0.450866 \\
0.0021^{*}\end{array}$ & $\begin{array}{c}1.00000 \\
-----\end{array}$ & - & - & - & - & - \\
\hline AGE35_54 & $\begin{array}{c}0.009577 \\
0.9508\end{array}$ & $\begin{array}{l}0.86106 \\
0.0000^{*}\end{array}$ & 1.00000 & - & - & - & - \\
\hline WORKSEEKERS_MALE & $\begin{array}{c}-0.121840 \\
0.4308\end{array}$ & $\begin{array}{l}0.78711 \\
0.0000 *\end{array}$ & $\begin{array}{l}0.98669 \\
0.0000 *\end{array}$ & 1.000000 & - & - & - \\
\hline WORKSEEKERS_FEM & $\begin{array}{c}-0.115259 \\
0.4563\end{array}$ & $\begin{array}{l}0.79073 \\
0.0000^{*}\end{array}$ & $\begin{array}{l}0.98861 \\
0.0000^{*}\end{array}$ & $\begin{array}{c}0.999824 \\
0.0000^{*}\end{array}$ & 1.000000 & - & - \\
\hline BUSCONF & $\begin{array}{c}0.328674 \\
0.0294 *\end{array}$ & $\begin{array}{c}-0.29167 \\
0.0548\end{array}$ & $\begin{array}{c}-0.17478 \\
0.2565\end{array}$ & $\begin{array}{c}0.081933 \\
0.5970\end{array}$ & $\begin{array}{c}-0.09178 \\
0.5535\end{array}$ & 1.000000 & - \\
\hline GFCF & $\begin{array}{c}0.398955 \\
0.0073^{*}\end{array}$ & $\begin{array}{l}0.75210 \\
0.0000^{*}\end{array}$ & $\begin{array}{l}0.67400 \\
0.0000 *\end{array}$ & $\begin{array}{c}0.662350 \\
0.0000^{*}\end{array}$ & $\begin{array}{c}0.657628 \\
0.0000 *\end{array}$ & $\begin{array}{c}0.039654 \\
0.7983\end{array}$ & 1.000000 \\
\hline
\end{tabular}

BUSCONF, business confidence; GFCF, gross fixed capital formation

$*, P$-value significant at $5 \%$ significance level.

TABLE 3: Augmented Dickey-Fuller unit root tests results.

\begin{tabular}{|c|c|c|c|c|c|c|}
\hline \multirow[t]{2}{*}{ Variables } & \multicolumn{2}{|c|}{ Levels } & \multicolumn{3}{|c|}{ 1st Difference } & \multirow[t]{2}{*}{ Order of integration } \\
\hline & Intercept & Intercept and trend & None & Intercept & Intercept and trend & \\
\hline ABSORP & 0.0617 & 0.2399 & 0.2689 & $0.0023^{*}$ & - & I (1) \\
\hline AGE15_34 & 0.8942 & 0.1512 & 0.8324 & $0.0000 *$ & - & I (1) \\
\hline AGE35_54 & 0.9974 & 0.3848 & 1.0000 & $0.0000 *$ & - & I (1) \\
\hline WORKSEEKERS_FEM & 1.0000 & 0.6897 & 0.9955 & $0.02687^{*}$ & $0.0106^{*}$ & I (1) \\
\hline WORKSEEKERS_MALE & 0.4078 & 0.9926 & 0.3789 & 0.5464 & $0.0124 *$ & I (1) \\
\hline BUSCONF & 0.9974 & 0.3848 & 1.0000 & $0.0000 *$ & - & I (1) \\
\hline
\end{tabular}

ADF, augmented Dickey-Fuller; BUSCONF, business confidence; GFCF, gross fixed capital formation.

$*, P$-value significant at $5 \%$ significance level. 


\section{Model selection}

In this study, the ARDL approach will be used to test cointegration long-run and short-run relationships as proposed by Pesaran and Shin (1997). This study used the Akaike information criterion (AIC) as a guide to choose the maximum lag-order of 1 . The ARDL model was, therefore, specified using the appropriate lag-length selection criterion. As such, the model chosen is $(1,0,0,1,1,0,1)$. The autoregressive distributed lag model will then be considered as ARDL $(1,0)$. Table 4 broadly provides the optimal ARDL model.

\section{Autoregressive distributed lag bounds tests and estimated long-run equation}

To test whether there exists a long-run relationship between the variables, the bound test for cointegration is executed as recommended by Pesaran et al. (2001).

The study utilised the bounds test of co-integration to test the long-run relationship of employment factors on labour absorption rate. The study was formulated under the hypothesis that:

\section{$H_{0}$ : There is no existence of co-integration between the variables}

\section{$H_{1}$ : There is existence of co-integration between the variables}

In reference to Pesaran et al. (2001), it is imperative to compare the $F$-statistic with the critical values of the $1 \%, 5 \%$ and $10 \%$ significance level. The chosen level of significance was at 5\%, therefore, as can be seen in Table 5, the estimated F-statistic value for the selected optimal ARDL model is 11.44399 which is greater than the corresponding critical value bounds. Therefore, the null hypothesis of cointegration (i.e. no longrun relationship) is rejected, hence confirming that there is a long-run relationship between the labour absorption rate and the selected variables. Thus, it can be deduced that changes in the selected independent variables have an impact on labour absorption in South Africa. Equation 2 summarises the nature of the long-run relationship between the selected explanatory variables and labour absorption.

\section{ABSORP $=-6.351744+0.007828 \mathrm{LBUSCONF}+$ $0.000023 \mathrm{LGFCF}+0.001700 \mathrm{LAGE} 15 \_34+$ 0.001576 LAGE35 $54+$ 0.015000 LWORKSEEKERS fem - 0.015268LWORKSEEKERS male}

TABLE 4: Optimal Autoregressive Distributed Lag model selected.

\begin{tabular}{lcc}
\hline ARDL model & Maximum number of lags & Selected model \\
\hline $\begin{array}{l}\text { Employment vs. factors } \\
\text { affecting labour absorption }\end{array}$ & 1 & $\operatorname{ARDL}(1,0,0,1,1,0,1)$ \\
\hline
\end{tabular}

ARDL, autoregressive distributed lag model.

TABLE 5: Estimated Autoregressive Distributed Lag model bound test results.

\begin{tabular}{lcccc}
\hline $\begin{array}{l}\text { Estimated } \\
\boldsymbol{F} \text {-statistic }\end{array}$ & $\begin{array}{c}\text { Critical value } \\
\text { bounds (Sig.) (\%) }\end{array}$ & $\begin{array}{c}\text { Lower bound } \\
\mathbf{( \% )}\end{array}$ & $\begin{array}{c}\text { Upper bound } \\
\mathbf{( \% )}\end{array}$ & Decision \\
\hline 11.44399 & 10 & 2.1 & 3.23 & Reject \\
& 5 & 2.45 & 3.61 & Reject \\
& 2.5 & 2.75 & 3.99 & Reject \\
& 1 & 3.15 & 4.43 & Reject \\
\hline
\end{tabular}

As stipulated by the long-run relationship results, business confidence positively affects labour absorption rate in South Africa. This denotes that a one-unit increase in business confidence will bring a change of $0.007828 \%$ or $7.828 \%$ in labour absorption rates, however, the variable has a probability value that is greater than both 0.05 and 0.1 significance level, which implies that the variable does not have a significant impact on labour absorption rate. Gross fixed capital formation (GFCF) appears to positively impact the rate of labour absorption; this is observed by one additional unit in GFCF that will lead to a $0.000023 \%$ or $2.3 \%$ increase in the labour absorption rate. This indicates that investments in gross capital formation are likely to enable workers to be absorbed by the labour market, that is, become employed.

According to Dordoni and Argentero (2015), the age stereotypes in the hiring processes appear to be a barrier to employment. In this case, this study categorised age difference into two categories of age15_34 and age35_54, particularly focusing on the youth and experienced cohorts. Labour force age15_34 shows to be a preferred group relative to that of labour force age35_54. In the long run, labour force age15_34 appears to have a positive impact on the labour absorption rate, which means that a one-unit increase in labour force age15_34 leads to a rise in the rate of labour absorption by $0.001700 \%$ or $1.7 \%$. On the other hand, labour force 35_54 seems to also positively affect labour absorption rate. A one-unit increase in labour force age35_54 will lead to a $0.001576 \%$ or $1.576 \%$ increase in labour absorption rate.

The number of females entering the labour market appears to have a positive impact on the labour absorption rate, which implies that a one-unit increase in the number of females entering the labour market will result in $0.01500 \%$ or $1.5 \%$ rise in labour absorption rate. In other words, female work-seekers increases the employment rate, which is indicative of increased employment opportunities for females in particular; this is an increased likelihood of females to be absorbed into the labour market, which is greater than that of males. In contrast, the number of males entering the labour market seems to have a negative impact on labour absorption, which means that a one-unit increase in the number of males entering the labour market will result in $-0.015268 \%$ or $1.527 \%$ decline in labour absorption. These findings could be ascribed to employment policies that aim to redress and balance the longstanding gender discrimination in the workplace (Kring 2017). The World Bank also reports that women-friendly policies have shown to contribute positively to company profitability, which is mostly likely to induce many companies to employ more females relative to males (World Bank 2014). In addition, firms that employ females are reported to be much more effective than those with all-male employees (Burunciuc 2018). South Africa's past is characterised by a legacy of apartheid and oppression, which saw millions of racial groups and females being systematically discriminated against (South African Human Rights Commission 2012:5). In addressing gender inequality in employment, policies are 
most likely to push firms to give advantage to females over males because they are historically disadvantaged, which could explain why females are most likely to increase the labour absorption rate in South Africa.

\section{Short-run analysis and the error correction model (ECM)}

After the approval of the long-run equilibrium coefficients of labour absorption equation, the short-run model will be estimated (Table 6). The primary objective of this study is to analyse factors affecting labour absorption in South Africa. The bounds test has revealed that there is a long-run equilibrium between labour absorption rate and selected employment variables; therefore, it is also important to analyse the short-run relationship. The approach to analyse the short-run relationship will be based on the ECM. According to Brooks (2014), the ECM is utilised to test how long it takes for the variables to return to equilibrium. Therefore, the EC term or CointEq $(-1)$ defines the speed of adjustment of the variables to equilibrium.

As shown in Table 6, the error correction term is estimated at -1.175004 and is highly significant with a probability value of 0.0000 . This suggests that the speed of adjustment towards a long-run relationship is $1.175004 \%$ quarterly or the system adjusts the disturbances or any movements into disequilibrium within one quarter. Furthermore, given large $t$-stats of -8.503007 , it can be concluded that the coefficient is highly significant. It is also evident that the EC term conforms to the requirements because it is negative and significant at the 0.05 and 0.1 significance level. This further implies that all the variables are cointegrated.

According to Belloumi (2014), the EC term as represented by CointEq (-1) confirms the existence of a long-run relationship. As evidenced in Table 6, it can be seen that, in the short run, the number of males entering the labour market has a negative impact on labour absorption although the variable is significant at the 0.05 significance level. Therefore, in the short run, a one-unit increase in the number of males entering the labour market will lead to a decrease in labour absorption rate by $-0.017940 \%$ or $1.794 \%$. This explains that despite the number of males entering the labour market, male workseekers make no significant contribution to labour absorption rate in South Africa. Again, this could be attributed to shifts in employment policies, which are in favour of female workseekers. On the other hand, female work-seekers are still significant to the labour absorption rate because a one-unit

TABLE 6: Estimated error correction model (ECM) results.

\begin{tabular}{lcccc}
\hline Variable & Coefficient & SE & $t$-statistic & Probability \\
\hline D(LWORKSEEKERS_male) & -0.017940 & 0.004681 & -3.832381 & $0.0006^{*}$ \\
D(LWORKSEEKERS_fem) & 0.017625 & 0.005863 & 3.005938 & $0.0051^{*}$ \\
D(LGFCF) & 0.000012 & 0.000004 & 3.140585 & $0.0036^{*}$ \\
D(LAGE15_34) & 0.000906 & 0.000509 & 1.780220 & 0.0845 \\
D(LAGE35_54) & 0.001852 & 0.000928 & 1.995802 & 0.0545 \\
D(LBUSCONF) & 0.021572 & 0.011062 & 1.949979 & $0.0600^{*}$ \\
CointEq(-1) & -1.175004 & 0.138187 & -8.503007 & $0.0000^{*}$ \\
\hline
\end{tabular}

$\mathrm{SE}$, standard error.

$*, P$-value significant at $5 \%$ significance level. increase in the number of females entering the labour market will pose changes in the labour absorption rate by $0.017625 \%$ or $1.7625 \%$.

Business confidence has proven to be the most important contributor to labour absorption rate in South Africa. The results have shown that, in the short run, a one-unit increase in business confidence will ultimately lead to a 0.021572 or 2.1572 increase in the labour absorption rate. These findings imply that employers are most likely to increase their hiring during economic upswings in the business cycle, whilst a weak economic environment characterised by demand slack and uncertainty will likely induce a negative effect on the decision to increase employment (Kazan 2012; Pratomo 2015). This, therefore, means those looking for work during periods of low business confidence are most likely to take longer before finding employment. Moreover, GFCF appears to be the most important recommendation for improvements in labour absorption, because it contributes significantly to both the long-run and short-run equilibrium. In the short run, a one-unit increase in gross fixed capital will lead to a change in the labour absorption rate by $0.000012 \%$ or $1.2 \%$. This is because increased investments will result in increased demand for workers, which means those looking for work will stand a better chance of finding one. These findings mirror those of Lieuw-Kie-Song et al. (2019) and show how important investment spending is towards the creation of employment.

\section{Diagnostic tests}

To confirm whether the ARDL results are not spurious, the study made use of a diagnostic test (Table 7). The model has confirmed to have passed the diagnostic tests of heteroscedasticity, serial correlation and Jacque-Bera normality test as evidenced by non-rejected null hypothesis as shown in Table 6 . The results of the stability tests can also confirm that the relationships between labour absorption, age15_34, age35_54, Female work-seekers, male work-seekers, GFCF and business confidence were stable during the period of the sample.

The recursive estimation using CUSUM stability can conclude that the parameters remain stable over the course of the study, because both of the recursive lines are in the bound as

TABLE 7: Model diagnostic test results.

\begin{tabular}{|c|c|c|c|}
\hline Test statistics & $\begin{array}{l}\text { Null hypothesis } \\
\left(H_{0}\right)\end{array}$ & $\begin{array}{l}\text { Probability } \\
\text { value }\end{array}$ & Conclusions \\
\hline $\begin{array}{l}\text { Breusch-Pagan } \\
\text { Godfrey }\end{array}$ & $\begin{array}{l}\text { No } \\
\text { heteroscedasticity }\end{array}$ & $0.2598 *$ & $\begin{array}{l}\text { Do not reject the null } \\
\text { hypothesis because the } \\
\text { probability value is greater than } \\
0.05 \% \text {, the model does not } \\
\text { suffer from heteroscedasticity }\end{array}$ \\
\hline $\begin{array}{l}\text { Lagrange } \\
\text { multiplier test }\end{array}$ & $\begin{array}{l}\text { No serial } \\
\text { correlation }\end{array}$ & $0.9016 *$ & $\begin{array}{l}\text { Do not reject the null } \\
\text { hypothesis, the probability } \\
\text { value is greater than } 0.05 \% \text {, } \\
\text { therefore, there is no serial } \\
\text { correlation detected in the } \\
\text { model }\end{array}$ \\
\hline Jacque-Bera & $\begin{array}{l}\text { Residuals are } \\
\text { normally } \\
\text { distributed }\end{array}$ & $0.564944 *$ & $\begin{array}{l}\text { Do not reject the null } \\
\text { hypothesis because the } \\
\text { probability value is greater than } \\
\text { the } 0.05 \% \text { significance level, } \\
\text { therefore this suggests that the } \\
\text { residuals of the model are } \\
\text { normally distributed }\end{array}$ \\
\hline
\end{tabular}

*, Fail to reject the null hypothesis at $5 \%$ significance level. 


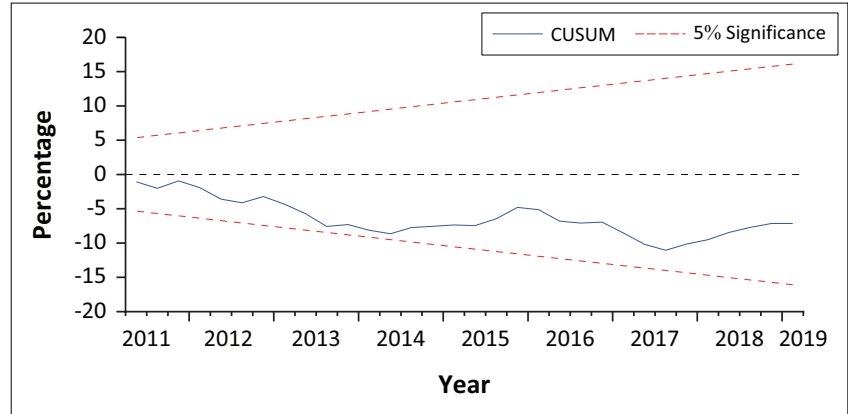

CUSUM, cumulative sum of recursive residuals.

FIGURE 2: Model stability diagnostic.

indicated by Figure 2. This test is done to detect the unknown structural breaks (Turner 2010). The study has not suffered from any structural breaks.

\section{Conclusions}

Labour absorption is imperative to labour policymakers for specific reasons. Firstly, it is a broader measure of labour market performance than unemployment, because it comprises the labour force participation behaviour. The second possible reason is that higher labour absorption rates are conducive to more opportunities and human development. The objective of this study was to analyse factors affecting labour absorption rate in South Africa. The analysis of the study suggests that there is a long-run relationship between the selected variables and labour absorption. South Africa's continually growing unemployment rates appear to be acute if measured by labour absorption. The consequence is that low absorption rates could continue to hinder the economic growth if factors affecting labour absorption rate are not clearly defined. Low levels of labour absorption in South Africa reflect the weak economy and they also indicate the gap in the labour market. According to the findings of this study, it is suggested that persistent efforts to understand factors affecting labour absorption in South Africa would ultimately help the labour market to absorb a large pool of both the skilled and unskilled labour. The misconceptions of factors affecting labour absorption rate are detrimental to progress in employment levels.

The findings, as shown, denotes that there is a need to reevaluate the labour policies in order to improve the labour market. Inequalities in the labour market have shown to be a deterrent to productivity levels; therefore, the trend of employment policies that combat gender disparity should be consistently nurtured to increase flexibility in the labour market, whilst tackling the persistent unemployment of the youth. The strength of labour market institutions is important in tackling unemployment levels, and therefore the government should strengthen the labour market institutions to ensure that they are inclusive and conducive to labour absorptive capacity. In addition, the joint evidence of GFCF and business confidence has shown the importance of these factors in improving labour absorption, which suggests that, in the long run, a continued investment in GFCF would lead to an improved labour market. The results of this study acknowledge the research gap or limitations in understanding the predominant factors affecting labour absorption. It is imperative for further studies on labour absorption to be undertaken in order to have a clear picture as to how policy, particularly improved policy-making, may address the issue of persisting gender gaps in employment in South Africa. The findings of this study provide a good indication that South Africa's gender employment policies could be working; however, it is acknowledged that females still dominate unemployment rates in South Africa, irrespective of racial group. This is proof enough that more improvements are needed in the current policy and economic landscape. Further research, which is inclusive of a wide range of variables, especially those relating to employment policies, is needed to have a better understanding of the dynamics surrounding labour absorption in South Africa.

\section{Acknowledgements Competing interests}

The authors declare that they have no financial or personal relationships that may have inappropriately influenced them in writing this article.

\section{Authors' contributions}

K.S. developed the theoretical formalism, performed the analytic calculations and performed the numerical simulations. Both K.S and P.M. contributed to the final version of the manuscript. P.M. supervised the project.

\section{Funding information}

This research received no specific grant from any funding agency in the public, commercial or not-for-profit sectors.

\section{Data availability}

The data that support the findings of this study are available in Statistics South Africa at http:/ /www.statssa.gov.za/.

\section{Disclaimer}

The views and opinions expressed in this article are those of the authors and do not necessarily reflect the official policy or position of any affiliated agency of the authors.

\section{References}

Altman, M., 2003, The state of employment and unemployment in South Africa, State of the Nation: South Africa, 2004, pp. 158-183, HRSC Press, Cape Town.

Arodoye, N.L. \& Iyoha, M.A., 2014, 'Foreign trade-economic growth nexus: Evidence from Nigeria', CBN Journal of Applied Statistics 5(1), 121-138.

Banerjee, A., Galiani, S., Levinsohn, J., McLaren, Z. \& Woolard, I., 2008, 'Why has unemployment risen in the New South Africa?', Economics of Transition 16(4), 715-740. https://doi.org/10.1111/j.1468-0351.2008.00340.x

Bazen, S. \& Skourias, N., 1997, 'Is there a negative effect of minimum wages on youth employment in France?', European Economic Review 41(3-5), 729-732.

Belloumi, M., 2014, 'The relationship between trade, FDI and economic growth in Tunisia: An application of the autoregressive distributed lag model', Economic Systems 38(2), 269-287. https://doi.org/10.1016/j.ecosys.2013.09.002

Bernstein, A., 2020, 'How the labour laws hold back job creation?', viewed 27 May 2020, from https://www.businesslive.co.za/bd/opinion/2020-01-29-how-thelabour-laws-hold-back-job-creation/. 
Bhorat, H., Dieden, S. \& Hodge, J., 1998, 'The impact of structural and production method changes on employment growth of occupational groups in South Africa', The Trade \& Industry Monitor 6(2), 1-54, viewed 17 September 2019, from http:// The Trade \& Industry Monitor 6 w.
www.tips.org.za/files/186.pdf.

Bhorat, H., Hirsch, A., Kanbur, S.R. \& Ncube, M., 2014, Economic policy in South Africa: Past, present, and future, Working Paper No. 642-2016-44220, Development Policy Research Unit, University of Cape Town, Cape Town.

Bhorat, H. \& Khan, S., 2018, Structural change and patterns of inequality in the South African labour market, Working Paper No. 201801, Development Policy Research Unit, University of Cape Town, Cape Town.

Bhorat, H. \& Leibbrandt, M., 1999, Modelling vulnerability and low earnings in the South African labour market, Working Paper No. 99/32, Development Policy Research Unit, University of Cape Town, Cape Town.

Bloemen, H.G., 1997, 'Job search theory, labour supply and unemployment duration' Journal of Econometrics 79(2), 305-325. https://doi.org/10.1016/S0304 4076(97)00025-0

Branson, N., De Lannoy, A. \& Brynde, K., 2019, Review of youth labour market research, National Income Dynamic Study (NIDS), SALDRU, Cape Town.

Brooks, C., 2014, Introductory econometrics for finance, Cambridge University Press, Cambridge.

Burunciuc, L., 2018, Why companies that employ women are more effective than 'all male' companies, viewed 02 December 2020, from https://www.worldbank.org/ en/news/opinion/2018/03/09/why-companies-that-employ-women-are-moreeffective-than-all-male-companies.

Chandra, V. \& Khan, M.A., 1993, 'Foreign investment in the presence of an informal sector', Economica 52(2), 79-103. https://doi.org/10.2307/2554732

Charles, K.K., Hurst, E. \& Schwartz, M., 2019, 'The transformation of manufacturing and the decline in US employment', NBER Macroeconomics Annual 33(1), 307-372. https://doi.org/10.1086/700896

Diamond, P.A., 1982, 'Wage determination and efficiency in search equilibrium', The Review of Economic Studies 49(2), 217-227. https://doi.org/10.2307/2297271

Dordoni, P. \& Argentero, P., 2015, 'When age stereotypes are employment barriers: A conceptual analysis and a literature review on older worker's stereotypes', Ageing International 40(4), 393-412. https://doi.org/10.1007/s12126-015-9222-6

Elrick, T. \& Lewandowska, E., 2008, 'Matching and making labour demand and supply: Agents in Polish migrant networks of domestic elderly care in Germany and Italy' Journal of Ethnic and Migration studies 34(5), 717-734. https://doi.org/10.1080/ 13691830802105954

Faggian, A. (ed.), 2014, 'Job search theory', in Handbook of regional science, pp. 60-72, Ohio State University, Columbus, $\mathrm{OH}$.

Gogtay, N.J. \& Thatte, U.M., 2017, 'Principles of correlation analysis', Journal of the Association of Physicians of India 65(3), 78-81, viewed 17 October 2019, https:// www.kem.edu/wp-content/uploads/2012/06/9-Principles of correlation-1.pdf.

Hundley, G., 2001, 'Domestic division of labor and self/organizationally employed differences in job attitudes and earnings', Journal of Family and Economic Issues 22(2), 121-139. https://doi.org/10.1023/A:1016678112790

Institute for Race Relations, 2017, Labour market absorption rate slips - IRR, viewed 03 November 2019, from https://irr.org.za/media/media-releases/labour-marketabsorption-rate-slips-2013-irr/view.

Jackman, R. \& Savouri, S., 1992, 'Regional migration in Britain: An analysis of gross flows using NHS central register data', The Economic Journal 102(415), 14331450. https://doi.org/10.2307/2234799

Kazan, M., 2012, Underemployment: Implications for organizations, Economic Research Institute, Redmond.

Keynes, J.M., 1936, The general theory of employment, interest, and money, Macmillan, London.

Kingdon, G. \& Knight, J., 2007, 'Unemployment in South Africa, 1995-2003: Causes, problems and policies', Journal of African Economies 16(5), 813-848. https://doi. org/10.1093/jae/ejm016

Kingdon, G.G. \& Knight, J., 2004, 'Unemployment in South Africa: The nature of the beast. World development', Journal of African Economies 32(3), 391-408. https:// doi.org/10.1016/j.worlddev.2003.10.005

Kring, S.A., 2017, Gender in employment policies and programmes: What works for women, Working Paper No. 235, International Labour Organization, Geneva.

Leibbrandt, M., Woolard, I., McEwen, H. \& Koep, C., 2010, Employment and inequality outcomes in South Africa, Southern Africa Labour and Development Research Unit, University of Cape Town, Cape Town.
Lieuw-Kie-Song, M., Adebe, H., Sempundu, T. \& Bynens, E., 2019, Employment impact assessments: Analysis of the employment effects of infrastructure investment in Rwanda using multiplier analysis of construction subsectors, Working Paper No.14, International Labour Organization, Geneva.

McCall, J.J., 1970, 'Economics of information and job search', The Quarterly Journa of Economics 1(1), 113-126. https://doi.org/10.2307/1879403

Meyer, D.F., 2014, 'Job creation, a mission impossible? The South African case' Mediterranean Journal of Social Sciences 5(16), 65-77. https://doi.org/10.5901/ mjss.2014.v5n16p65

Mlatsheni, C. \& Ranchhod, V., 2017, 'Youth labour market dynamics in South Africa: Evidence from NIDS 1-2-3.' REDI3x3 Working Paper 39, School of Economics and SALDRU, University of Cape Town, Cape Town.

Moleke, P., 2005, A review of labour markets in South Africa: Education and training, HRSC Press, Cape Town.

Mothibi, L. \& Mncayi, P., 2019, 'Investigating the key drivers of government debt in South Africa: A post-apartheid analysis', International Journal of eBusiness and eGovernment Studies 11(1), 16-33. https://doi.org/10.34111/ijebeg.20191112

Oosthuizen, M. \& Bhorat, H., 2005, The post-apartheid South African labour market, Working Paper No. 05, Development Policy Research Unit, University of Cape Town, Cape Town.

Pesaran, M.H. \& Shin, Y., 1997, Testing for unit roots in heterogeneous panels, Revised version of the DAE Working Paper No. 9526, University of Cambridge, Cambridge.

Pesaran, M.H., Shin, Y. \& Smith, R.J., 2001, 'Bounds testing approaches to the analysis of level relationships', Journal of Applied Econometrics 16(3), 289-326. https:// doi.org/10.1002/jae.616

Pickles, A. \& Rogerson, P., 1984, 'Wage distributions and spatial preferences in competitive job search and migration', Regional Studies 18(2), 131-142. https:// doi.org/10.1080/09595238400185131

Posel, D. \& Casale, D., 2003, What has been happening to internal labour migration in South Africa, 1993-1999?, Working Paper No. 03/74, Division of Economics, University of Cape Town, Cape Town.

Potts, D., 2008, 'The urban informal sector in sub-Saharan Africa: From bad to good (and back again?)', Development Southern Africa 25(2), 151-167. https://doi. org/10.1080/03768350802090527

Pratomo, D.S., 2015, The analysis of underemployment in Indonesia: Determinants and its implication', Procedia - Social and Behavioral Sciences 211, 528-532. https://doi.org/10.1016/j.sbspro.2015.11.070

Schwab, K., 2018, The global competitiveness report, viewed 08 October 2019, from http://www3.weforum org/docs/GCR2017-2018/05FullReport/TheGlobalCompe titivenessReport $2017 \% \mathrm{E} 2 \% 80 \% 932018$.pdf.

Sjaastad, L.A., 1962, 'The costs and returns of human migration', Journal of Political Economy 70(5,2), 80-93. https://doi.org/10.1086/258726

South African Human Rights Commission, 2012, South African Human Rights Commission Equality Report, viewed 01 December 2020, from https://www.sahrc. org.za/home/21/files/Equality \%20Report $\% 2020 \% 200$ ct $\% 202012 \% 20$ Final.pdf.

Statistics South Africa, 2019, Unemployment rises slightly in third quarter of 2019 viewed 06 November 2019, from http://www.statssa.gov.za/?p=12689.

Statistics South Africa, 2020, Quarterly labour force survey Q2:2020, viewed 01 December 2020, from http://www.statssa.gov.za/publications/P0211/ Presentation\%20QLFS\%20Q2 2020.pdf.

Turner, P., 2010, 'Power properties of the CUSUM and CUSUMSQ tests for parameter instability', Applied Economics Letters 17(11), 1049-1053. https://doi.org/ 10.1080/00036840902817474

Van den Berg, G.J., 1990, 'Non-stationarity in job search theory', The Review of Economic Studies 57(2), 255-277. https://doi.org/10.2307/2297381

Van der Berg, S. \& Burger, R., 2003, Education and socio-economic differentials A study of school performance in the Western Cape, Working Paper No. 03/73, Development Policy Research Unit, University of Cape Town, Cape Town.

Verick, S. \& Islam, I., 2010, The great recession of 2008-2009: Causes, consequences and policy responses, Discussion Paper No. 4934, International Labour Organization (ILO), IZA Institute of Labor Economics, Griffith University, Bonn.

World Bank, 2014, Gender at work: A companion to the World Development Report on jobs, viewed 01 December 2020, from https://www.worldbank.org/content/dam/ Worldbank/Event/Gender/GenderAtWork_web2.pdf.

World Bank, 2018, Jobs and inequality, viewed 19 March 2019, from http://pubdocs worldbank.org/en/798731523331698204/South-Africa-Economic-UpdateApril-2018.pdf. 